
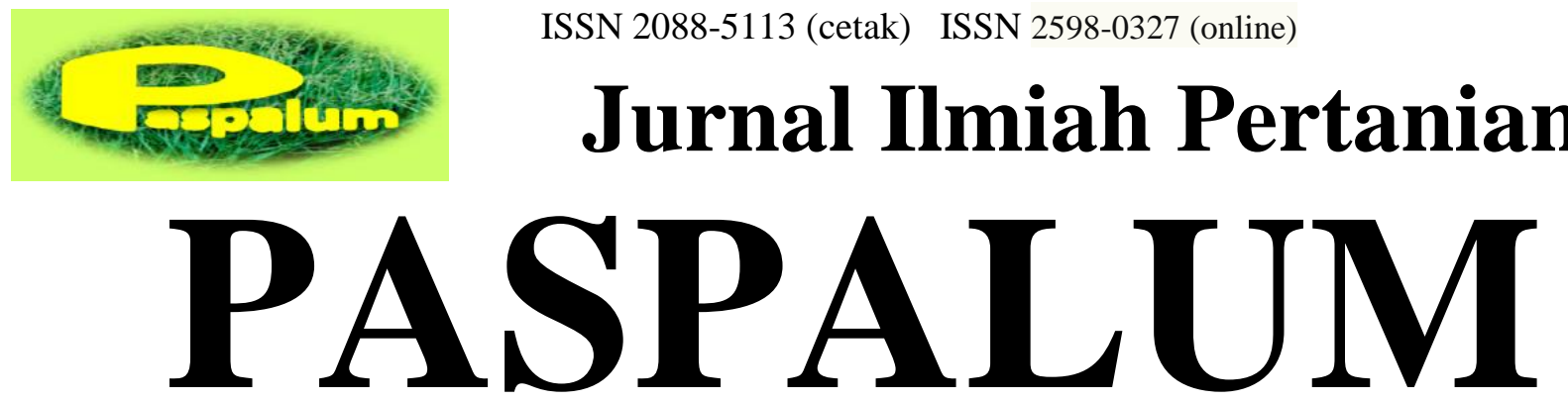

Volume. 6 No. 1 Bulan Maret Tahun 2018

http://journal.unwim.ac.id/index.php/paspalum

\title{
Uji Efektivitas Berbagai Konsentrasi Jenis Nutrisi Alternatif Terhadap Produksi Jamur Tiram Putih (Pleurotus ostreatus) di Kabupten Karawang
}

\author{
Rommy Andhika Laksono, Fawzy Muhamad Bayfurqon, \\ dan Miftakhul Bakhrir R.K \\ Program studi Agroteknologi Fakultas Pertanian Universitas Singaperbangsa. \\ rommy.laksono@staff.unsika.ac.id
}

Diterima tgl : 12-02-2018 dan disetujui untuk diterbitkan tgl : 31-03-2018

\begin{abstract}
In the development of modern agriculture based on location specification agriculture, to increase the production of white oyster mushrooms, requires able to utilize alternative natural resources that are easy to obtain and efficient.The research was conducted with the aim to study and get the concentration of alternative nutrient types that can provide the highest production of white oyster mushroom in Karawang regency. Based on the purpose, this research is verifikatif.The method used is experimental method and experiment design used is single factor randomized block design (RAK) consisting of 17 treatments in 3 repetitions : A (100\% Aquades Concentration); B (20\% Leri Water Concentration); C (40\% Leri Water Concentration); D (60\% Leri Water Concentration); E (80\% Leri Water Concentration); F (20\% Potato Skin Extract Concentration); G (40\% Potato Skin Extract Concentration); H (60\% Potato Skin Extract Concentration); I (80\% Potato Skin Extract Concentration); J (20\% Bean Sprouts Extract Concentration); K (40\% Bean Sprouts Extract Concentration); L (60\% Bean Sprouts Extract Concentration); M (80\% Bean Sprouts Extract Concentration); N (20\% Old Coconut Water Concentration); O (40\% Old Coconut Water Concentration); P (60\% Old Coconut Water Concentration); $Q(80 \%$ Old Coconut Water Concentration). The effect of treatment was analyzed by $F$ test of $5 \%$ level and if significant, then to know the best treatment was continued with Duncan Multiple Range Test at 5\% real level. The results achieved from this research is the application of various types of concentrations of alternative nutrients have a real effect on total clumps per baglog, total hood per clumps, maximum hood diameter per baglog, harvest intensity per baglog, dry weight of mushrooms per baglog, and fresh weight of mushrooms per baglog white oyster mushroom in Karawang regency. $80 \%$ concentration of leri water is able to give the highest growth and yield of white oyster mushroom in Karawang regency, with fresh weight of mushroom reach 142,35 gr per baglog per week or 0,85 tons per 1000 baglog in one plant period (6 MSA).
\end{abstract}

Keywords: Type of nutrition, Concentration, and White oyster mushroom.

\section{Abstrak}

Pada perkembangan pertanian modern yang berdasarkan pada pertanian spesifikasi lokasi, untuk meningkatkan produksi jamur tiram putih, mengharuskan mampu memanfaatkan sumberdaya alam alternatif yang mudah didapat dan efisien. Penelitian dilakukan dengan tujuan untuk mempelajari dan mendapatkan konsentrasi jenis nutrisi alternatif yang mampu memberikan produksi jamur tiram putih tertinggi di Kabupaten Karawang. Berdasarkan tujuan tersebut, maka penelitian ini bersifat verifikatif. Metode yang digunakan adalah metode eksperimen dan rancangan percobaan yang digunakan adalah Rancangan Acak Kelompok (RAK) faktor tunggal yang terdiri dari 17 perlakuan dalam 3 kali ulangan : A(Konsentrasi 100\% Aquades);B (Konsentrasi 20\% Air Leri); C(Konsentrasi 40\% Air Leri); D(Konsentrasi 60\% Air Leri); E(Konsentrasi 80\% Air Leri); F(Konsentrasi 20\% Ekstrak Kulit Kentang); G(Konsentrasi 40\% Ekstrak Kulit Kentang); H(Konsentrasi 60\% Ekstrak Kulit Kentang); I(Konsentrasi 80\% Ekstrak Kulit Kentang); J(Konsentrasi 20\% Ekstrak Tauge); K(Konsentrasi 40\% Ekstrak Tauge); L(Konsentrasi 60\% Ekstrak Tauge); M(Konsentrasi 80\% Ekstrak Tauge); 
N(Konsentrasi 20\% Air Kelapa Tua); O(Konsentrasi 40\% Air Kelapa Tua); P(Konsentrasi 60\% Air Kelapa Tua); $\mathrm{Q}($ Konsentrasi $80 \%$ Air Kelapa Tua). Pengaruh perlakuan dianalisis dengan sidik ragam dan apabila uji $\mathrm{F}$ taraf $5 \%$ signifikan, maka untuk mengetahui perlakuan yang paling baik dilanjutkan dengan uji lanjut DMRT (Duncan Multiple Range Test) pada taraf nyata 5\%. Hasil yang dicapai dari penelitian ini adalah aplikasi berbagai konsentrasi jenis nutrisi alternatif memberikan pengaruh yang nyata terhadap jumlah rumpun buah per baglog, jumlah tudung buah per rumpun, diameter tudung buah maksimal per baglog, intensitas panen per baglog, bobot kering jamur per baglog, bobot segar jamur per baglog jamur tiram putih di Kabupaten Karawang. Konsentrasi $80 \%$ air leri mampu memberikan pertumbuhan dan hasil tertinggi jamur tiram putih di Kabupaten Karawang, dengan hasil bobot segar jamur mencapai 142,35 gr per baglog per minggu atau 0,85 ton per 1000 baglog dalam satu periode tanam (6 MSA).

Kata Kunci : Jenis nutrisi, Konsentrasi, dan Jamur tiram putih

\section{PENDAHULUAN}

Karawang merupakan wilayah agraris yang memiliki sektor hortikultura yang potensial dan belum terkelola secara maksimal. Wilayah Karawang merupakan dataran rendah yang dibedakan menjadi dua yakni lahan kering (tegalan, kebun, ladang, padang rumput, dll) dan lahan sawah (sawah teknis, sawah setengah teknis, dan sawah tadah hujan). Kurangnya informasi dan teknologi tepat guna kepada petani Jamur tiram putih dalam mengembangkan pertanian Jamur di Karawang menjadi salah satu masalah penting. Jamur merupakan salah satu komoditas hortikultur yang saat ini memiliki peluang sangat besar untuk dikembangkan, salah satunya adalah Jamur Tiram Putih (Pleurotus ostreatus var. florida). Jamur ini dapat diolah menjadi berbagai makan yang digemari masyarakat. Dilihat dari kandungan gizinya, jamur tiram putih mampu menggantikan nilai gizi daging bagi para vegetarian.

Jamur tiram putih mempunyai nilai kandungan gizi yang cukup tinggi yaitu karbohidrat, protein, lemak, serat kasar, $\mathrm{Ca}, \mathrm{Fe}$, thiamin, riboflavin, sedangkan vitamin dan mineral yang terkandung didalamnya antara lain zinc, besi, kalium, kalsium, fosfor, vitamin $\mathrm{C}$, asam folat, niasin, vitamin B-1 dan B-2 (Widyastuti, 2008). Selain sebagai bahan pangan, jamur tiram juga bermanfaat sebagai obat untuk menurunkan kadar kolesterol darah, mencegah tekanan darah tinggi, meningkatkan kadar gula darah, meningkatkan daya tahan tubuh dan mencegah tumor atau kanker (Hedritomo, 2008).

Permintaan terhadap jamur tiram putih dari tahun ke tahun memang terus mengalami peningkatan. Permintaan jamur tidak hanya sebatas pasar dalam negeri, tetapi juga merambat hingga ke pasar internasional. Meskipun demikian produksi jamur tiram di Indonesia hanya mampu memenuhi $50 \%$ dari permintaan pasar dalam negeri, belum termasuk permintaan pasar luar negeri (Nugraha, 2015). Padahal, kebutuhan jamur tidak hanya terbatas pada permintaan jamur segar, masih ada peluang besar pada beberapa segmen usaha yang berkaitan erat dengan bisnis jamur. Misalnya, bisnis bibit jamur (inokulan), bisnis penjualan media jamur (baglog), bisnis olahan jamur, bisnis jasa dan pelatihan budidaya jamur, serta bisnis bidang agrowisata jamur (Rahmat dan Nurhidayat, 2011).

Budidaya Jamur Tiram tidak memerlukan lahan luas dan keahlian khusus. Namun, untuk meningkatkan produktivitas Jamur Tiram Putih perlu diperhatikan nutrisi yang diberikan. Nutrisi yang dibutuhkan untuk pertumbuhan jamur tiram putih antara lain karbohidrat, protein, mineral dan vitamin. Pada perkembangan pertanian modern yang berdasarkan pada pertanian spesifikasi lokasi, untuk meningkatkan produksi komoditas pertanian, mengharuskan mampu memanfaatkan sumberdaya alam alternatif yang mudah didapat dan efisien. Ada beberapa sumber nutrisi yang mengandung karbohidrat, protein, mineral dan vitamin yang dapat dimanfaatkan salah satunya air leri dan air rebusan kentang.

Peluang peningkatan produksi dan produktivitas jamur tiram putih di Karawang masih sangat terbuka lebar baik melalui penambahan nutrisi dan peningkatan teknologi budidaya. Nutrisi sangat berperan dalam proses 
budidaya jamur tiram. Nutrisi bahan baku atau bahan yang ditambahkan harus sesuai dengan kebutuhan hidup jamur tiram.

Air leri (air cucian beras) banyak mengandung gizi seperti vitamin B1 dan B 12 (Achmad, dkk.2011) Air leri mengandung unsur $\mathrm{N}, \mathrm{P}, \mathrm{K}, \mathrm{C}$ dan unsur lainnya. Berdasarkan hasil penelitan, air cucian beras tersebut dapat digunakan untuk nutrisi bagi pertumbuhan Jamur Tiram Putih. Menurut Utami, dkk (2014) konsentrasi $20 \mathrm{ml}$ air leri : $80 \mathrm{ml}$ aquades mampu memberikan jumlah tubuh buah dan lebar tudung jamur tiram terbaik pada pengujian di Yogyakarta.

Kulit kentang tidak banyak orang yang memanfaatanya dan dibuang begitu saja. Kulit kentang diduga memiliki kandungan senyawa polifenol. Kandungan senyawa fenolik dalam kulit kentang memungkinkan tingginya antioksidan dan mampu meningkatkan pertumbuhan sel (Schieber dan Saldana, 2009).

Menurut Soeprapto (1992) pada kecambah kacang hijau (Touge) komponen air merupakan bagian yang terbesar dibandingkan dengan komponen lainnya. Gula kacang hijau didapatkan dalam bentuk sukrosa, fruktosa, dan glukosa. Asam amino esensial yang terkandung dalam protein kacang hijau antara lain triptofan $1,35 \%$, treonin $4,50 \%$, fenilalanin $7,07 \%$, metionin $0,84 \%$, lisin 7,94 $\%$, leusin $12,90 \%$, isoleusin $6,95 \%$, valin 6,25 $\%$. Menurut Maulana (2010), triptofan merupakan bahan baku sintesis IAA.

Air kelapa merupakan salah satu produk tanaman yang dapat dimanfaatkan untuk meningkatkan pertumbuhan jamur tiram. Air kelapa yang sering dibuang oleh para pedagang di pasar tidak ada salahnya bila dimanfaatkan penambah nutrisi bagi jamur tiram. Hasil penelitian menunjukkan bahwa air kelapa kaya akan kalium, mineral diantaranya Kalsium $(\mathrm{Ca})$, Natrium (Na), Magnesium (Mg), Ferum $(\mathrm{Fe})$, Cuprum $(\mathrm{Cu})$, dan Sulfur $(\mathrm{S})$, gula dan protein. Disamping kaya mineral, dalam air kelapa juga terdapat 2 hormon alami yaitu auksin dan sitokinin yang berperan sebagai pendukung pembelahan sel (Barlina, dkk. 2007).

\section{BAHAN DAN METODE}

Penelitian ini dilaksanakan di Kumbung Jamur Tiram Fakultas Pertanian UNSIKA Kabupaten Karawang. Waktu percobaan dari bulan April- Agustus 2017. Metode yang digunakan adalah metode eksperimen dan rancangan percobaan yang digunakan adalah Rancangan Acak Kelompok (RAK) faktor tunggal yang terdiri dari 17 perlakuan dalam 3 kali ulangan: A(Konsentrasi 100\% Aquades); B (Konsentrasi 20\% Air Leri); C(Konsentrasi 40\% Air Leri); D(Konsentrasi 60\% Air Leri); E(Konsentrasi $80 \%$ Air Leri); F(Konsentrasi 20\% Ekstrak Kulit Kentang); G(Konsentrasi 40\% Ekstrak Kulit Kentang); H(Konsentrasi 60\% Ekstrak Kulit Kentang); I(Konsentrasi 80\% Ekstrak Kulit Kentang); J(Konsentrasi 20\% Ekstrak Tauge); K(Konsentrasi 40\% Ekstrak Tauge); L(Konsentrasi 60\% Ekstrak Tauge); M(Konsentrasi 80\% Ekstrak Tauge); N(Konsentrasi 20\% Air Kelapa Tua); O(Konsentrasi $40 \%$ Air Kelapa Tua); P(Konsentrasi $60 \%$ Air Kelapa Tua); Q(Konsentrasi 80\% Air Kelapa Tua). Pengaruh perlakuan dianalisis dengan sidik ragam dan apabila uji $\mathrm{F}$ taraf 5\% signifikan, maka dilanjutkan dengan uji lanjut DMRT (Duncan Multiple Range Test) pada taraf nyata 5\% untuk mengetahui perlakuan yang paling baik.

Variabel yang diamati meliputi pengamatan penunjang dan pengamatan utama, pengamatan penunjang ialah pengamatan yang datanya tidak diuji secara statistika namun mampu mendukung data utama dan pengamatan utama ialah pengamatan yang datanya diuji secara statistika.

Pengamatan penunjang meliputi: Serangan OPT (Organisme Pengganggu Tumbuhan), Keadaan iklim mikro kumbung (suhu dan kelembaban). Sedangkan pengamatan utama meliputi : jumlah rumpun buah per baglog (6 MSA), jumlah tudung buah per rumpun (6 MSA), diameter tudung buah maksimal per baglog (6 MSA), intensitas panen per baglog (6 MSA), bobot kering jamur per baglog (6 MSA), bobot segar jamur per baglog (6 MSA). 


\section{HASIL DAN PEMBAHASAN}

\section{Keadaan Iklim Mikro Kumbung}

Suhu harian kumbung selama percobaan berlangsung berkisar antara $26,21{ }^{0} \mathrm{C}$ $29,83^{\circ} \mathrm{C}$ dengan rata-rata suhu $28,02{ }^{\circ} \mathrm{C}$. Hal ini sesuai dengan pernyataan (Rahmat, S. dan Nurhidayat, 2011), bahwa suhu optimum untuk pertumbuhan miselium jamur tiram putih berkisar antara $25^{\circ} \mathrm{C}-30^{\circ} \mathrm{C}$ dan untuk pertumbuhan bakal buah membutuhkan suhu ruangan normal yang berkisar $25-28^{\circ} \mathrm{C}$.

Kelembaban relative kumbung selama percobaan berlangsung berkisar 64,05 \% $82,93 \%$ dengan rata-rata kelembaban 73,49\%. Hal ini sesuai dengan pernyataan (Rahmat, S. dan Nurhidayat, 2011) bahwa kelembaban udara yang dibutuhkan untuk pertumbuhan jamur tiram di atas $60-80 \%$.

Melihat rata rata suhu harian dan kelembaban relatif kumbung selama percobaan sangat ideal untuk pertumbuhan dan perkembangan jamur tiram putih karena kondisi lingkungan yang baik akan meningkatkan produksi hifa untuk menyusun pertumbuhan miselium yang lebih optimal dan jika didukung dengan ketersediaan nutrisi yang tepat akan meingkatkan jumlah tudung jamur yang akan mempengaruhi bobot segar jamur tiram. Sesuai dengan pernyataan Dewi (2009), Faktor-faktor lingkungan sangat mempengaruhi pertumbuhan jamur tiram putih seperti air, keasaman $(\mathrm{pH})$, substrat, kelembaban, suhu udara, dan ketersediaan sumber nutrisi.

\section{Organisme Pengganggu Tanaman (OPT)}

Selama percobaan berlangsung tidak ditemukan adanya serangan hama dan penyakit hal ini disebabkan pada saat akan melakukan percobaan, kumbung jamur disterilkan terlebih dahulu dengan cara menyemprotkan desinfektan secara menyeluruh ke seluruh bagian kumbung sehingga terhindar dari serangan hama. Selain itu selama percobaan berlangsung sanitasi dan kondisi kumbung selalu terjaga sehingga terhidar dari pertumbuhan cendawan penyebab penyakit.

Jumlah Rumpun Buah, Jumlah Tudung Buah Per Rumpun, dan Diameter Tudung Buah Maksimal
Hasil uji $F$ pada analisis ragam menunjukkan bahwa terdapat pengaruh nyata pemberian berbagai konsentrasi jenis nutrisi alternatif terhadap jumlah rumpun buah, jumlah tudung buah per rumpun, dan diameter tudung buah maksimal jamur tiram putih (Tabel 1).

Pengaplikasian nutrisi alternatif dengan berbagai konsentrasi mampu memberikan pengaruh nyata terhadap jumlah rumpun buah, jumlah tudung buah per rumpun, dan diameter tudung buah maksimal jamur tiram putih. Konsentrasi $80 \%$ air leri, $40 \%$ ekstra kulit kentang, 60\% ekstrak tauge, dan 60\% air kelapa tua mampu memberikan jumlah rumpun buah, jumlah tudung buah per rumpun, dan diameter tudung buah maksimal jamur tiram putih tertinggi pada setiap jenis nutrisi. Konsentrasi $80 \%$ air leri secara konsisten mampu memberikan hasil jumlah rumpun buah per minggu tertinggi sebesar 5,27 buah per baglog, jumlah tudung buah per rumpun tertinggi sebesar 52,76 buah per baglog, dan diameter tudung buah maksimal tertinggi sebesar 11,67 $\mathrm{cm}$ per baglog.

\section{Intensitas Panen Per Minggu, Bobot Kering Jamur Per Minggu, dan Bobot Segar Jamur Per Minggu}

Hasil uji $F$ pada analisis ragam menunjukkan bahwa terdapat pengaruh nyata pemberian berbagai konsentrasi jenis nutrisi alternatif terhadap intensitas panen per minggu, bobot kering per minggu, dan bobot segar per minggu jamur tiram putih(Tabel 2).

Pengaplikasian nutrisi alternatif dengan berbagai konsentrasi mampu memberikan pengaruh nyata terhadap intensitas panen per minggu, bobot kering jamur per minggu, dan bobot segar jamur per minggu. Konsentrasi $80 \%$ air leri, $40 \%$ ekstra kulit kentang, $60 \%$ ekstrak tauge, dan 60\% air kelapa tua mampu memberikan intensitas panen per minggu, bobot kering jamur per minggu, dan bobot segar jamur per minggu tertinggi pada setiap jenis nutrisi. Konsentrasi $80 \%$ air leri secara konsisten mampu memberikan hasil intensitas panen per minggu tertinggi sebesar 3,70 kali per minggu, bobot kering jamur per minggu tertinggi sebesar 10,07 gr per baglog, dan bobot segar jamur per minggu tertinggi sebesar 142,35 gr per baglog. 
Tabel 1. Pengaruh berbagai konsentrasi jenis nutrisi alternatif terhadap rata-rata jumlah rumpun buah, jumlah tudung buah per rumpun, dan diameter tudung buah maksimal.

\begin{tabular}{|c|c|c|c|c|c|}
\hline \multirow[b]{2}{*}{ No } & \multirow[b]{2}{*}{ Perlakuan } & \multirow[b]{2}{*}{ Konsentrasi (\%) } & \multicolumn{3}{|c|}{1 Periode Tanam (6 Minggu) } \\
\hline & & & $\begin{array}{c}\text { Rata Rata Jumlah } \\
\text { Rumpun Buah per } \\
\text { Minggu } \\
\text { (Buah/Baglog) } \\
\end{array}$ & $\begin{array}{c}\text { Rata Rata Jumlah } \\
\text { Tudung Buah Per } \\
\text { Rumpun Per Minggu } \\
\text { (Buah/Baglog) }\end{array}$ & $\begin{array}{c}\text { Rata Rata Diameter } \\
\text { Tudung Buah } \\
\text { Maksimal Per } \\
\text { Minggu }(\mathrm{cm} / \text { Baglog })\end{array}$ \\
\hline A & Aquades & 100 & $3,64 \mathrm{~cd}$ & $33,36 \mathrm{~cd}$ & $6,20 \mathrm{~d}$ \\
\hline $\mathrm{B}$ & Air Leri & 20 & $3,78 \mathrm{~cd}$ & 43,40 abcd & $6,78 \mathrm{~d}$ \\
\hline $\mathrm{C}$ & Air Leri & 40 & $4,67 a b c$ & $48,09 a b$ & $10,37 \mathrm{ab}$ \\
\hline $\mathrm{D}$ & Air Leri & 60 & $3,61 \mathrm{~cd}$ & $42,32 \mathrm{abcd}$ & $7,60 \mathrm{~cd}$ \\
\hline $\mathrm{E}$ & Air Leri & 80 & $5,27 \mathrm{a}$ & 52,76 a & 11,67 a \\
\hline $\mathrm{F}$ & Ekstrak Kulit Kentang & 20 & 4,33 abcd & 43,90 abcd & $6,06 \mathrm{~d}$ \\
\hline $\mathrm{G}$ & Ekstrak Kulit Kentang & 40 & $4,83 \mathrm{ab}$ & $50,22 \mathrm{ab}$ & $10,37 \mathrm{ab}$ \\
\hline $\mathrm{H}$ & Ekstrak Kulit Kentang & 60 & $3,83 \mathrm{bcd}$ & 40,21 abcd & $6,44 \mathrm{~d}$ \\
\hline I & Ekstrak Kulit Kentang & 80 & $3,72 \mathrm{~cd}$ & 40,83 abcd & $6,86 \mathrm{~d}$ \\
\hline $\mathbf{J}$ & Ekstrak Tauge & 20 & $3,89 \mathrm{bcd}$ & 43,56 abcd & $6,81 \mathrm{~d}$ \\
\hline K & Ekstrak Tauge & 40 & $4,06 \mathrm{bcd}$ & $36,54 \mathrm{bcd}$ & $6,82 \mathrm{~d}$ \\
\hline $\mathrm{L}$ & Ekstrak Tauge & 60 & 4,39 abcd & $50,64 \mathrm{a}$ & $10,57 \mathrm{ab}$ \\
\hline M & Ekstrak Tauge & 80 & $3,78 \mathrm{~cd}$ & 40,13 abcd & $6,71 \mathrm{~d}$ \\
\hline $\mathrm{N}$ & Air Kelapa Tua & 20 & 4,33 abcd & 41,96 abcd & $6,67 \mathrm{~d}$ \\
\hline $\mathrm{O}$ & Air Kelapa Tua & 40 & 4,33 abcd & $31,08 \mathrm{~d}$ & $6,84 \mathrm{~d}$ \\
\hline $\mathrm{P}$ & Air Kelapa Tua & 60 & 4,50 abcd & $49,31 \mathrm{ab}$ & $8,98 \mathrm{bc}$ \\
\hline $\mathrm{Q}$ & Air Kelapa Tua & 80 & $3,56 \mathrm{~d}$ & $46,54 \mathrm{abc}$ & $8,76 \mathrm{c}$ \\
\hline & $\mathrm{CV} \%$ & & 12,88 & 15,92 & 11,24 \\
\hline
\end{tabular}

Keterangan : Nilai rata-rata yang ditandai dengan huruf yang sama pada setiap kolom yang sama tidak berbeda nyata pada uji lanjut DMRT 5\%

Tabel 2. Pengaruh berbagai konsentrasi jenis nutrisi alternatif terhadap rata-rata intensitas panen per minggu, bobot kering jamur per minggu, Bobot segar jamur per minggu.

\begin{tabular}{|c|c|c|c|c|c|}
\hline \multirow[b]{2}{*}{ No } & \multirow[b]{2}{*}{ Perlakuan } & \multirow[b]{2}{*}{ Konsentrasi (\%) } & \multicolumn{3}{|c|}{1 Periode Tanam (6 Minggu) } \\
\hline & & & $\begin{array}{c}\text { Rata Rata Intensitas } \\
\text { Panen Per Minggu } \\
\text { (Kali/Baglog) }\end{array}$ & $\begin{array}{c}\text { Rata Rata Bobot Kering } \\
\text { Jamur per Minggu } \\
\text { (gr/Baglog) }\end{array}$ & $\begin{array}{c}\text { Rata Rata Bobot } \\
\text { Segar Jamur per } \\
\text { Minggu (gr/Baglog) } \\
\end{array}$ \\
\hline A & Aquades & 100 & $2,11 \mathrm{e}$ & $7,31 \mathrm{c}$ & $58,31 \mathrm{~h}$ \\
\hline B & Air Leri & 20 & $2,72 \mathrm{~d}$ & $7,32 \mathrm{c}$ & 82,06 defg \\
\hline $\mathrm{C}$ & Air Leri & 40 & $3,67 \mathrm{a}$ & $9,24 \mathrm{~b}$ & $106,65 \mathrm{bc}$ \\
\hline $\mathrm{D}$ & Air Leri & 60 & $3,00 \mathrm{bcd}$ & $7,67 \mathrm{c}$ & $91,72 \mathrm{cdef}$ \\
\hline $\mathrm{E}$ & Air Leri & 80 & $3,70 \mathrm{a}$ & 10,07 a & 142,35 a \\
\hline $\mathrm{F}$ & Ekstrak Kulit Kentang & 20 & $2,89 \mathrm{~d}$ & $7,48 \mathrm{c}$ & 87,17 cdef \\
\hline $\mathrm{G}$ & Ekstrak Kulit Kentang & 40 & $3,50 \mathrm{ab}$ & $9,26 \mathrm{~b}$ & $121,74 \mathrm{bc}$ \\
\hline $\mathrm{H}$ & Ekstrak Kulit Kentang & 60 & $2,78 \mathrm{~d}$ & $7,38 \mathrm{c}$ & 77,53 efgh \\
\hline I & Ekstrak Kulit Kentang & 80 & $2,89 \mathrm{~d}$ & $7,42 \mathrm{c}$ & $86,53 \mathrm{cdef}$ \\
\hline $\mathbf{J}$ & Ekstrak Tauge & 20 & $2,67 \mathrm{~d}$ & $7,61 \mathrm{c}$ & $69,39 \mathrm{fgh}$ \\
\hline $\mathrm{K}$ & Ekstrak Tauge & 40 & $2,61 \mathrm{de}$ & $7,35 \mathrm{c}$ & $71,31 \mathrm{fgh}$ \\
\hline $\mathrm{L}$ & Ekstrak Tauge & 60 & $3,50 \mathrm{ab}$ & $9,15 \mathrm{~b}$ & $101,39 \mathrm{bcd}$ \\
\hline M & Ekstrak Tauge & 80 & $2,94 \mathrm{~cd}$ & $7,63 \mathrm{c}$ & $60,32 \mathrm{gh}$ \\
\hline $\mathrm{N}$ & Air Kelapa Tua & 20 & $2,89 \mathrm{~d}$ & $7,38 \mathrm{c}$ & $87,58 \mathrm{cdef}$ \\
\hline $\mathrm{O}$ & Air Kelapa Tua & 40 & $2,61 \mathrm{de}$ & $7,30 \mathrm{c}$ & 79,81 defgh \\
\hline $\mathrm{P}$ & Air Kelapa Tua & 60 & $3,44 \mathrm{abc}$ & $9,33 \mathrm{~b}$ & 99,42 cde \\
\hline $\mathrm{Q}$ & Air Kelapa Tua & 80 & $2,94 \mathrm{~cd}$ & $7,57 \mathrm{c}$ & 77,46 efgh \\
\hline \multicolumn{3}{|c|}{$\mathrm{CV} \%$} & 9,69 & 3,26 & 13,75 \\
\hline
\end{tabular}

Keterangan : Nilai rata-rata yang ditandai dengan huruf yang sama pada setiap kolom yang sama tidak berbeda nyata pada uji lanjut DMRT 5\% 


\section{Bobot Segar Jamur Per 1000 Baglog, dan Bobot Segar Jamur Satu Periode Tanam Per 1000 Baglog}

Hasil uji $F$ pada analisis ragam menunjukkan bahwa terdapat pengaruh nyata pemberian berbagai konsentrasi jenis nutrisi alternatif terhadap bobot segar per 1000 baglog, dan bobot segar satu periode tanam per 1000 baglog jamur tiram putih (Tabel 3).

Pengaplikasian nutrisi alternatif dengan berbagai konsentrasi mampu memberikan pengaruh nyata terhadap bobot segar jamur per 1000 baglog, dan bobot segar jamur satu periode tanam per 1000 baglog. Konsentrasi $80 \%$ air leri, $40 \%$ ekstra kulit kentang, $60 \%$ ekstrak tauge, dan $60 \%$ air kelapa tua mampu memberikan bobot segar jamur per 1000 baglog, dan bobot segar jamur satu periode tanam per 1000 baglog tertinggi pada setiap jenis nutrisi. Konsentrasi $80 \%$ air leri mampu memberikan hasil bobot segar jamur per 1000 baglog tertinggi sebesar $142,35 \mathrm{~kg}$, dan bobot segar jamur satu periode tanam per 1000 baglog sebesar 0,85 ton.

\section{Pembahasan}

Hasil percobaan secara konsisten menunjukan pemberian konsentrasi jenis nutrisi altertanif yang berbeda mampu meningkatkan pertumbuhan dan hasil jamur tiram putih. Hasil percobaan juga memperlihatkan setiap jenis nutrisi mampu memberikan konsentrasi optimal terhadap komponen pertumbuhan dan hasil jamur tiram putih.

Konsentrasi $80 \%$ air leri, $40 \%$ ekstra kulit kentang, 60\% ekstrak tauge, dan 60\% air kelapa tua, mampu memberikan pengaruh terbaik disetiap jenis nutrisi terhadap seluruh komponen pertumbuhan dan hasil jamur tiram putih. Hal ini terjadi karena setiap jenis nutrisi mengandung karbohidrat, protein, dan vitamin yang mampu meningkatkan produksi hifa dalam membentuk miselium jamur tiram putih. Penambahan nutrisi alternatif, mampu mengakumulasi karbohidrat dalam jumlah yang lebih banyak dapat mempercepat pertumbuhan tubuh buah dan menambah berat basah jamur tiram putih. Karbohidrat diperlukan pada pertumbuhan jamur tiram karena karbohidrat menjadi bahan utama bagi hifa untuk dipecah menjadi senyawa-senyawa sederhana seperti glukosa yang berguna dalam proses metabolisme jamur tiram putih.

Selain karbohidrat unsur yang penting bagi pertumbuhan jamur tiram putih adalah nitrogen. Nitrogen diperlukan sebagai penyusun asam amino organik di dalam enzim dan protein dalam proses metabolisme jamur tiram putih. selain itu akumulasi nitrogen akibat pemberian nutrisi alternatif mampu mempercepat pertumbuhan miselium dalam pembentukan tudung buah jamur tiram putih. Adanya kandungan karbohidrat dan protein yang tinggi pada jamur tiram putih mampu meningkatkan metabolismenya sehingga merangsang pertumbuhan miselium dan produksi tubuh buah. Hasil percobaan ini menunjukan konsentrasi $80 \%$ air leri mampu memberikan komponen pertumbuhan dan hasil tertinggi dari semua jenis nutrisi yang diberikan. Hal ini diduga terjadi karena air leri merupakan nutrisi alternatif yang memiliki kandungan unsur hara, hormon, dan vitamin lebih komplek dibandingkan dengan ekstrak tauge, ekastrak kulit kentang, dan air kelapa tua. Air leri memiliki kandungan unsur N,P,K, dan $\mathrm{C}$ yang lebih banyak dibandingan dengan jenis nutrisi yang lainya dalam percobaan ini.

Konsentrasi $80 \%$ air leri juga diduga mampu meningkatkan kandungan hormon auksin yang berfungsi untuk merangsang pertumbuhan dan pemanjangan sel dan mampu meningkatkan kandungan hormon sitokinin yang berperan dalam pembelahan sel. Konsentrasi hormon yang optimal dapat mempengaruhi pertumbuhan dan perkembangan jamur tiram putih salah satunya berat basah tanaman (Tabel 2) dengan syarat pemberian konsentrasi nutrisi yang tepat dan optimal. Menurut Mufarrihah, (2009) kandungan nutrisi yang semakin meningkat akan mempengaruhi kinerja hormon untuk lebih aktif dalam mendegradasi senyawasenyawa tersebut, sehingga akan meningkatkan pertumbuhan miselium. 
38 I Paspalum: Jurnal IImiah Pertanian Vol.6, No.1, Maret 2018

Tabel 3. Pengaruh berbagai konsentrasi jenis nutrisi alternatif terhadap rata-rata Bobot segar jamur per minggu per 1000 baglog, Bobot segar jamur satu periode tanam per 1000 baglog.

\begin{tabular}{|c|c|c|c|c|}
\hline \multirow[b]{2}{*}{ No } & \multirow[b]{2}{*}{ Perlakuan } & \multirow[b]{2}{*}{ Konsentrasi (\%) } & \multicolumn{2}{|c|}{ Rata-Rata } \\
\hline & & & $\begin{array}{c}\text { Bobot Segar Jamur } \\
\text { Per minggu }(\mathrm{kg} / 1000 \\
\text { Baglog) }\end{array}$ & $\begin{array}{c}\text { Bobot Segar Jamur satu } \\
\text { periode tanam (6 MSA) } \\
\text { (ton/1000 Baglog) }\end{array}$ \\
\hline $\mathrm{A}$ & Aquades & 100 & $58,31 \mathrm{~h}$ & 0,35 \\
\hline $\mathrm{B}$ & Air Leri & 20 & 82,06 defg & 0,49 \\
\hline $\mathrm{C}$ & Air Leri & 40 & $106,65 \mathrm{bc}$ & 0,64 \\
\hline $\mathrm{D}$ & Air Leri & 60 & $91,72 \mathrm{cdef}$ & 0,55 \\
\hline $\mathrm{E}$ & Air Leri & 80 & $142,35 \mathrm{a}$ & 0,85 \\
\hline $\mathrm{F}$ & Ekstrak Kulit Kentang & 20 & $87,17 \mathrm{cdef}$ & 0,52 \\
\hline $\mathrm{G}$ & Ekstrak Kulit Kentang & 40 & $121,74 \mathrm{~b}$ & 0,73 \\
\hline $\mathrm{H}$ & Ekstrak Kulit Kentang & 60 & 77,53 efgh & 0,47 \\
\hline I & Ekstrak Kulit Kentang & 80 & $86,53 \mathrm{cdef}$ & 0,52 \\
\hline $\mathbf{J}$ & Ekstrak Tauge & 20 & $69,39 \mathrm{fgh}$ & 0,42 \\
\hline $\mathrm{K}$ & Ekstrak Tauge & 40 & $71,31 \mathrm{fgh}$ & 0,43 \\
\hline $\mathrm{L}$ & Ekstrak Tauge & 60 & $101,39 \mathrm{bcd}$ & 0,61 \\
\hline M & Ekstrak Tauge & 80 & $60,32 \mathrm{gh}$ & 0,36 \\
\hline $\mathrm{N}$ & Air Kelapa Tua & 20 & $87,58 \mathrm{cdef}$ & 0,53 \\
\hline $\mathrm{O}$ & Air Kelapa Tua & 40 & 79,81 defgh & 0,48 \\
\hline $\mathrm{P}$ & Air Kelapa Tua & 60 & 99,42 cde & 0,60 \\
\hline \multirow[t]{2}{*}{$\mathrm{Q}$} & Air Kelapa Tua & 80 & 77,46 efgh & 0,46 \\
\hline & $\mathrm{CV} \%$ & & 15,51 & \\
\hline
\end{tabular}

Keterangan : Nilai rata-rata yang ditandai dengan huruf yang sama pada setiap kolom yang sama tidak berbeda nyata pada uji lanjut DMRT 5\%

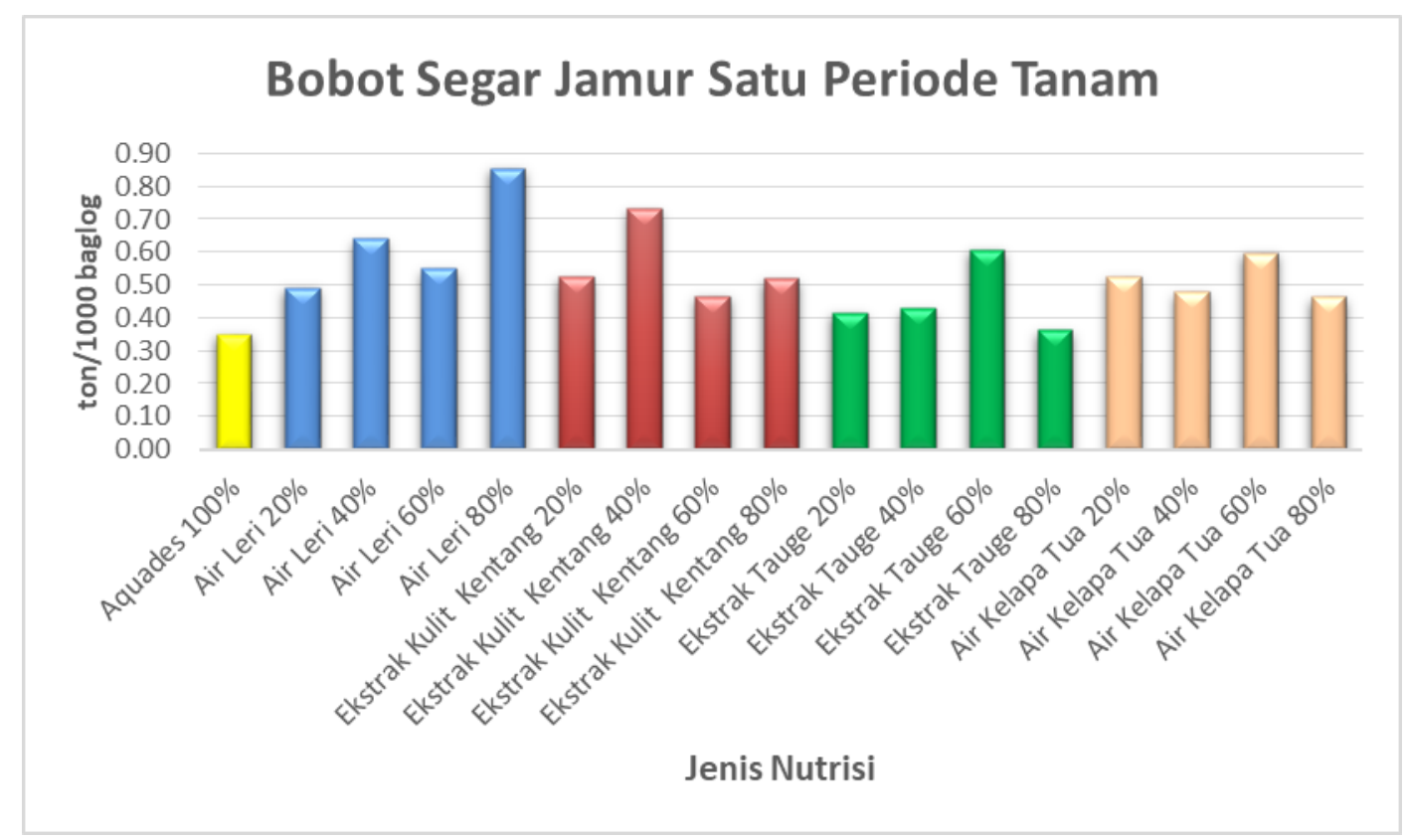

Gambar 1. Diagram Bobot Segar Jamur Satu Periode Tanam 
Unsur Nitrogen mampu mempercepat miselium dan pembentukan tudung, sesuai dengan hasil percobaan ini yang menunjukan konsentrasi $80 \%$ air leri mampu memberikan jumlah rumpun buah, jumlah tudung buah per rumpun tertinggi (Tabel 1). Unsur Posfor memiliki kemampuan dalam meningkatkan fase vegetatif jamur tiram putih seperti batang buah dan tudung buah, sesuai dengan hasil percobaan dimana konsentrasi $80 \%$ air leri mampu memberikan diameter tudung buah maksimal tertinggi (Tabel 1). Unsur Kalium mampu meningkatkan perkembangan primordia dan pertumbuhan tubuh buah, sesuai dengan hasil percobaan dimana konsentrasi $80 \%$ air leri mampu memberikan intensitas panen per minggu, bobot kering jamur per minggu, dan bobot segar jamur per minggu tertinggi (Tabel 2).

Pertumbuhan jamur tiram putih dapat berlangsung optimal apabila unsur hara esensial yang dibutuhkan tersedia dan dapat memenuhi kebutuhan pertumbuhan dan perkembanganya. Bila konsentrasi nutrisi alternatif yang diberikan terlalu tinggi maka laju pertumbuhan akan terganggu dan jika konsentrasi terlalu rendah maka akan menyebabkan terhambatnya pertumbuhan. Hal ini sejalan dengan Suriawiria (2002) bahwa nutrisi yang tersedia dalam media tanam mampu diserap oleh jamur akan mampu meningkatkan berat basah dari jamur. Berat basah jamur juga dipengaruhi oleh banyak sedikitnya kandungan air dalam tubuh buah jamur. Berat basah jamur berkaitan dengan ketersediaan sumber nutrisi dalam subtrat ( Nurafles, 2015).

\section{KESIMPULAN}

Aplikasi berbagai konsentrasi jenis nutrisi alternatif memberikan pengaruh yang nyata terhadap jumlah rumpun buah per baglog, jumlah tudung buah per rumpun, diameter tudung buah maksimal per baglog, intensitas panen per baglog, bobot kering jamur per baglog, bobot segar jamur per baglog jamur tiram putih di Kabupaten Karawang. Konsentrasi $80 \%$ air leri mampu memberikan pertumbuhan dan hasil tertinggi jamur tiram putih di Kabupaten Karawang, dengan hasil bobot segar jamur mencapai 142,35 gr per baglog per minggu atau 0,85 ton per 1000 baglog dalam satu periode tanam (6 MSA).

\section{UCAPAN TERIMA KASIH}

Peneliti mengucapkan terimaksih kepada Rektor UNSIKA, Dekan Faperta UNSIKA dan LPPM UNSIKA yang telah memberikan kesempatan dan membiayai penelitian ini melalui skema DIPA UNSIKA Tahun 2017.

\section{DAFTAR PUSTAKA}

Achmad, dkk. 2011. Panduan Lengkap Jamur. Jakarta: Penebar Swadaya.

Amilah, Astuti Y. 2006. Pengaruh Konsentrasi Ekstrak Taoge dan Kacang Hijau pada Media Vacin dan Went (VW) terhadap Pertumbuhan

Barlina, dkk. 2007. Pengaruh Perbandingan Air Kelapa dan Penambahan Daging Kelapa Muda Serta Lama Penyimpanan Terhadap Serbuk Minuman Kelapa. Jurnal Littri. Balai Penelitian Tanaman Kelapa dan Palma Lain (Balitka). 13(12) : 73-80.

Dewi, I.K. 2009. Efektifitas Pemberian Blotong Kering Terhadap Pertumbuhan Jamur Tiram Putih (Pleurotus ostreatus) pada Media Serbuk kayu. Skripsi. Universitas Muhammadiyah Surkarta.

Djarijah, N.M., Djarijah A. S. (2001). Jamur Tiram Pembibitan, Pemeliharaan dan Pengendalian Hama-Penyakit. Penerbit Kanisius, Yogyakarta

Gunawan, A.W., 2004. Usaha Pembibitan Jamur. Penebar Swadaya Jakarta.

Hedritomo, H. I., D. Tjokrokusumo, dan I. Djajanegara. 2008. Pengaruh Mutasi Radiasi Sinar Gamma (Co60) Terhadap Produksi Jamur Tiram Putih (Pleurotus ostreatus Jack.). Jurnal Biotika (6): 8-14. http://www.scribd.com/doc/25831070/Pen garuhKonsentrasiEkstrak-Taoge (11 Januari 2017).

Kiswanto, Y dan Saryanto, S. 2004. Pengaruh Suhu Lama Penyimpanan Air Kelapa Terhadap Produksi Nata De Coco. Intitusi Pertanian INTAN Yogyakarta.

Maulana, A. I.. 2010. Pengaruh Ekstrak Tauge (Phaseoulus radiates) Terhadap Kerusakan Sel Ginjal Mencit (Mus musculus) Yang Diinduksi Parasetamol. Skripsi. Surakarta: Universitas Sebelas Maret. 
Mufarrihah, L. 2009. Pengaruh Penambahan Bekatul dan Ampas Tahu Pada Media Terhadap Pertumbuhan dan Produksi Jamur Tiram Putih (Peurotus ostreatus). Skripsi. Fakultas Sains dan Teknologi Universitas Islam Negeri (UIN) Malang.

Moore, e and Landecker., 1982. Fundamental of The fungi. Prentice Hall, Inc. Englewoo Cliff, new Jersey. p 275, 337.

Nugraha, Tatang. 2015. Kiat Sukses Budidaya Jamur Tiram. Yrama Widya.Jakarta.

Nurafles, R. 2015. Pengaruh Komposisi Serbuk Gergajian Kayudan Jerami Padi Terhadap Pertumbuhan dan Hasil jamur Tiram Putih (Pleurotus ostreatus). Program Studi Agroteknologi Fakultas Pertanian Universitas Tamansiswa. Padang.

Nurdin, E. 2006. Aneka Olahan Kelapa. Penerbit Absolut. Yogyakarta.

Rahmat, S. dan Nurhidayat, 2011. Untung Besar dari Bisnis Jamur Tiram. Agro Media Pustaka. Jakarta.

Schieber, A., Saldana, M. D. A., 2009, Potato Peels: A Source of Nutritionally and Pharmacologically Interesting Compounds - A Review, Global Science Books, 3(2): 23-9.

Soenanto, Hardi.2000. Jamur Tiram: Budidaya Dan Peluang Usaha. Semarang: CV Aneka Ilmu.

Soeprapto, H. S.. 1992. Bertanam Kacang Hijau. Jakarta: Penebar Swadaya.

Suriawiria, U. 2002. Budidaya Jamur Tiram. Kanisius. Yogyakarta.

Utami, dkk.2014.Efektivitas Berbagai Konsentrasi Air Cucian Beras Terhadap Jumlah Tubuh Buah Dan Lebar Tudung Jamur Tiram Putih ( Pleurotus ostreatus ). Skripsi.Universitas Sanata Dharma. Yogyakarta.

Widyastuti, N. dan Istini, S. 2008. Optimasi Pengeringan Tepung Jamur Tiram (Pleurotus ostreatus) dengan Pengering Kabinet. Jurnal Teknologi Bioindustri 2(1): 30-33. 